\title{
Impact of External Governance Mechanism on the Performance of Listed Banks of Pakistan with the Moderating Role of Government Ownership
}

\author{
Shoaib Alia,"* \& Hafiz Muhammad Naveed ${ }^{\mathrm{b}}$ \\ ${ }^{a}$ School of Management, Jiangsu University, Zhenjiang 212013, China \\ ${ }^{b}$ School of Finance and Economics, Jiangsu University 301 Xuefu Road, Zhenjiang, Jiangsu Province, China
}

\begin{abstract}
This research aims to examine the external governance process boosts the performance of Pakistan's listed commercial banks by estimating the return on equity (ROE) and earnings per share (EPS). The research involved external governance mechanism with the moderating role of government ownership. The study's sample structure consists of Pakistan Stock Exchange (PSX) listed banks with the existence of government ownership from 2014 to 2018. Data is obtained as well from financial statements, shareholding trends, and the Credit Rating Agency of Pakistan (PACRA). To meet the specific aim of the research and to satisfy the goals of the analysis, the panel data methodology (fixed effect and random effect model) has been applied. The findings have shown that the external governance system plays an important role in the banking sector's accountability and performance. Government ownership may also improve banking institution efficiency by improving external governance mechanisms. This study will allow commercial banks to overcome the challenges and boost efficiency with the external governance mechanism and devise better working strategies. This study makes it easier for the bankers' rulers to run the external governance system to strengthen bank efficiency. This work is unique because no one defined an external governance system with government ownership as a moderating role.
\end{abstract}

Keywords: External governance system; Government ownership; banking system; Pakistan.

\section{Introduction}

The institution's primary purpose is to figure out the issues and then aim to remove the issues of implementing organizational regulations and lessening the misunderstanding. The poor corporate governance system and globalization of the financial and stock markets have disrupted the economic marketplace's stability domestically and globally (Al-Saidi \& Al-Shammari, 2013). In an entity, shareholders and consumers may belonging in the same region and may have a relationship with another country, and as such the top section of the authority has to determine and verify the efficiency of how issues can be avoided because they can be counterproductive to banking firms.

The accountability of stakeholders that administrators and organizations are failing due to personal benefits and weak governance structure (Tomar \& Bino, 2012). A group or entity is identified as investors who can impact the progress of the organization's objectives or preferences. The role of corporate governance is to provide a guarantee that management is trying to maximize shareholder returns. (Fidanoski et al., 2014) The stakeholder theory is the reverse of an agency's theory, as well as its director, is treated as an individual rather than a member. The primary relationships that describe deep corporate success are corporate efficiency and shareholder commitment.

A further need is the theory of resource dependence, which indicates a lack of both the knowledge and techniques of the organization necessary to achieve the desired outcomes and obtain operational goals. It depends on an institution's wealth and difficulties that extend the efficiency of the central agency (Pfeffer \& Salancik, 2003). The theories

\footnotetext{
* Corresponding author.

E-mail address: shooaibali6@gmail.com (Shoaib Ali)
} 
mentioned above propose a structure for corporate governance that enhances the effectiveness of organizations.

Banks are recognized as a middleman who receives, offers, and checks money from depositors on their behalf. (Mullineux, 2006) proposed that strong emphasis mostly on commercial banks is the main driver of developed countries' industrial prosperity. It has been identified that in the poorly developed banking institutions, the commercial banks constitute the most critical basis for the conventional funding of institutions as well as the central selection of funds. Therefore, the importance of both the financial sector on economic growth and the collapse of the commercial banks would also directly disrupt the monetary stream of the country (Bhagat \& Bolton, 2008).

To enhance commercial banks' performance, financial institutions, and external governance establish an operational condition involving leadership, customers, owners, and creditors. In Pakistan, the government structure the State Bank of Pakistan (SBP) code for banking was first adopted in 2003, but progressively it was revised and a modern governance structure was obtained, with changes from 2009 to 2011.

Pakistan is a developing economy and its banking sector faces challenges such as excessive interest rates, inflationary pressures or outflows of equity, restricted the reach of inputs, unjustified production and obligation loans, highly diversified management budgets, and union projection interference, slow decision-making, poor distributions of human capital, and poor external operations. Therefore, the specialists investigated the absence of a robust corporate governance structure as the key explanation for the weak success of the corporations.

The previous study focused on financial or non-financial companies to assess the association between corporate governance and business profitability. This research emphasizes the impact of the external governance mechanism on the point of view of commercial banks. The banking industry and the framework of corporate management are clarified by the institutions themselves. A narrower view of corporate governance that is attributed to financial companies should be implemented, impacting both investors and participants.

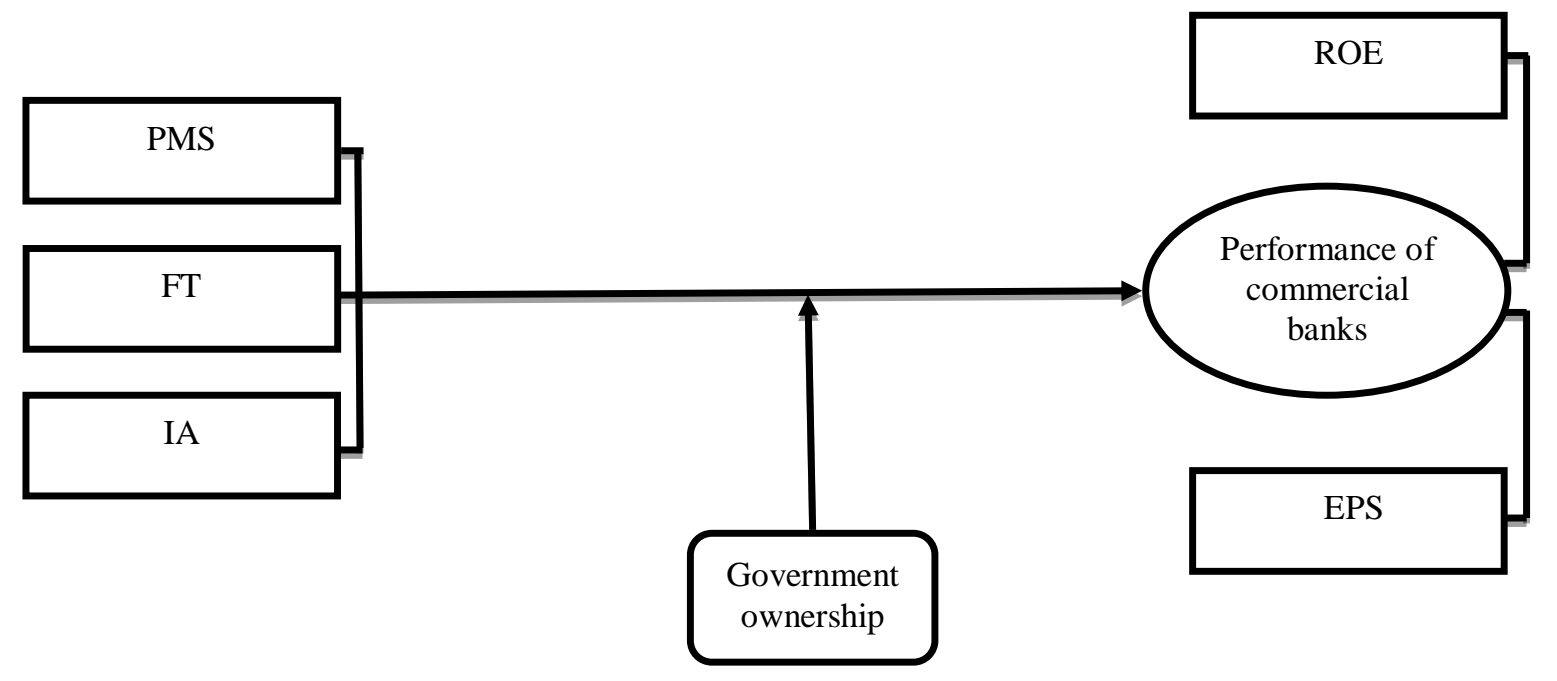

Fig. 1. Theoretical framework

This study aims to analyze the effect upon the results of listed banks in Pakistan of the external governance mechanism process. For commercial banks, there are separate standards for a governance system, while SBP summarizes in the form of fiduciary rules. This study brings some freshness to the recent literature. First of all, analysis establishes more descriptive, detailed, and banking institutions listed in PSX are the target population of the analysis and the sampling technique is purposive. We also have taken measures from the normative system of previous literature and have been using external frameworks to protect minority shareholders (PMS), financial transparency (FT), independent audit (IA), and government ownership as moderators. 


\section{Objectives of the research}

- To evaluate the impact of PMS on the performance of commercial banks with the moderator of government ownership.

- To analyze the impact of FT on the performance of commercial banks with the moderator of government ownership.

- To articulate the impact of IA on the performance of commercial banks with the moderator of government ownership.

\section{Literature Review}

Important evidence remains regarding the significance of the processes of governance of financial institutions. The governance structure will be able to diminish bank reserve turnovers and foster bank proficiency. Commercial banks have made a positive contribution to the efficiency of corporations (Bokov \& Vernikov, 2008). As a function of the fundamental commercial banks, financial institutions in Europe are compared with financial markets, functioning finance entities. To retain roles of shareholders, big creditors, financial advisers, corporation stake owners, stock market stakeholders, and convey voting rights by the PMS, there is no need to provide further part of the external governance structure (Giroud \& Mueller, 2010). Butt and Hasan (2009) highlighted that in a massive credit-ship situation where entities were banking organizations may play governance functions by reviewing the activities of the company, regular auditing, and implementing penalty fees, based on financial sector credit.

Therefore, the extensive governance mechanism of banking institutions increases the likelihood that banks can outperform sound governance structures over other entities. The connotation of external governance structure and commercial banking is described in the present study review. An organization's monetary strength is directly correlated with effective corporate governance (Weir et al., 2002). The arrangement of government ownership, the legal framework for PMS, FT, and IA are proactive steps that have a direct effect on the performance of banking firm processes.

The pattern seems to be that financial disputes exist between the minority shareholder and the majority of shareholders. This is a legal security structure for the PMS and its equity market trade (Chung et al., 2003). Corporate governance about the research permits, economic status, stock competitive pressures, autonomous legal systems, aspects of mainstream economics management, institutional development, investment mechanisms, and PMS reviews. Disagreements over the relevant PMS norm still exist. When discussing PMS, all kinds of specialists have conflicting viewpoints. There are so many close similarities regarding PMS replication methods, including poor management and avoidance of abuse. It also eliminates the costs inherent in the management of service payments by companies (Reese Jr \& Weisbach, 2002).

PMS is emulated by questions over the legitimacy of jury proceedings. Managers were also required to work together with PMS and other businesses, although certain tools for corporate governance efforts include clear compliance documents for minority shareholder lawsuits from management (Fischel \& Bradley, 1985). A minority in the value of the shareholder when they do not meet the minimum standard of deciding the compensation for a valuable result. A quantitatively appropriate method for calculating the poor operational return flow is not proposed by the researchers because it does not deliver accurate PMS behavioral outcomes (Reese Jr \& Weisbach, 2002).

\section{H1: PMS positively enhances the performance of commercial banks with government ownership as moderator.}

Financial transparency (FT) requires prompt, substantive, and precise reports regarding the financial performance of a business. To raise money, businesses need to have straightforward financial support (Lowenstein, 1996). Public trust is diminished by banking firms that have a negative impact on social and economic patterns that contribute to disappointing outcomes (Cadbury \& Cadbury, 2002). The procedural transparency and evidence show vital and relevant facets of the mechanism of governance. Corporate governance comprises the collection of standards for fostering openness, integrity, morality, fairness, equality, authority, and responsibility in the corporation's board of directors' rules and procedures (Lang et al., 2012). The corporate mechanism further explained that it satisfies the 
position of leadership, governing values, engagement, integrity, consideration for the interests of customers, operations, norms, governance policy, financial accountability, accuracy, and outcomes of success access (DiPiazza Jr \& Eccles, 2002). Therefore, for organizational systems, financial transparency and security of available data are essential.

There are corporate governance standards, community trust of information disclosure is considered an interactive element to identify the development of the organization. Non-binding past analysis details provided and deemed to be used to satisfy creditors and stock markets (Rodríguez Bolívar et al., 2013). In particular, there is indeed a negative correlation between FT and the performance of the organizations (Chen et al., 2007). The relationship between FT and institutional progress, on the other hand, is positive (Chong-En et al., 2006). If FT maintains a strong credit ranking, which increases its prestige, and more stockholders indulge in the acquisition, corporate efficiency may be improved.

H2: FT positively enhances the performance of commercial banks with government ownership as moderator.

An independent audit is a voluntary nonprofit's financial statements, reports, corporate activities, accounting procedures, and internal controls (Bronson et al., 2009). Independent audit (IA), which may monitor unregulated organizational operations, is an enhancement to the governance mechanism. It is clarified that even an external audit lowers guidance disparity between the management and the administrator based on corporate governance and eliminates potential conflict of interest (Watts \& Zimmerman, 1983).

The main role of the International Accounting Standard (IAS) for IA has been described as restoring the right to trust consumers in the appraisal of financial reports to maintain the atmosphere of transparency and to appease shareholders. The IAS would improve the oversight and prompt auditing of financial information by banking and corporate decision-makers during the IAS, including the use of statement mechanisms (Diamond, 2002). It is confirmed that penetration and monitoring rates minimize the asymmetry between internal and external facts and improve the efficiency of the business. (Al-Ghanem \& Hegazy, 2011) suggested during a discussion and removal of the capital market negative theories regarding results, it's really important to look only at potential and threats for negative transactions. However, minimizing the chance of assessments conducted by communicating with internal audit function, in particular those dealing with external auditing, is a core design feature. The research seems to have a major impact mostly on corporate auditors who collaborate with external auditors. This is therefore known to have effects that may lead to changes in the accounting report of the financial statements under-examined, which again is supervised by independent auditors. Hence, prompt activities executing audit processes and duties related to the audit. Previous analysis found a weak relationship with external auditors and a huge risk between independent audits and financial performance (Francis, 2004).

H3: IA positively enhances the performance of commercial banks with government ownership as moderator.

Government ownership performs and gathers key data to address between the primary government and the administrators who oversee and regulate the banking industries (La Porta et al., 2002). It proposed that the management government regulates the listed banks to conform with the legislation and standards to achieve the targets that could increase the conflict between the stockholders (Chong-En et al., 2006). Therefore, in special cases, government ownership of commercial banks causes the operator's judgment favorable to that same banking shareholder.

\section{Methods}

\subsection{Sample design and construction of variables}

The study's sample structure consists of Pakistan Stock Exchange (PSX) listed banks with the existence of government ownership from 2014 to 2018. Data is obtained as well from financial statements, shareholding trends, and the Credit Rating Agency of Pakistan (PACRA). However, during research PSX registered a total of 24 commercial banks. Consequently, banks were omitted with inadequate data and the final sample of data contained 22 registered banks.

To check the interaction of commercial banks' performance with ROE and EPS we evaluate the external governance 
mechanism with the PMS, FT, and IA. Moreover, we also examined the efficiency of listed banks with government ownership as moderator. Interpretations of these variables are described in Table 1. Two control variables, such as bank size and leverage, are used in the analysis to govern the particular aspects of the bank that can configure performance.

Table 1. Variables formation

\begin{tabular}{|c|c|c|c|}
\hline Variables & Class of variables & Variables definition & References \\
\hline Return on equity (ROE) & Dependent & $\begin{array}{l}\text { Computed by subtracting net } \\
\text { sales by the equity of owners. }\end{array}$ & (Damodaran, 2007) \\
\hline Earnings per share (EPS) & Dependent & $\begin{array}{l}\text { Profit is subdivided by } \\
\text { outstanding shares of its. }\end{array}$ & (Hunjra et al., 2014) \\
\hline $\begin{array}{l}\text { Protection of minority } \\
\text { shareholders (PMS) }\end{array}$ & Independent & $\begin{array}{l}\text { If the securities on the share } \\
\text { markets are traded, then } 1 \text {, else } \\
0 .\end{array}$ & (Chong-En et al., 2006) \\
\hline $\begin{array}{l}\text { Financial transparency } \\
\text { (FT) }\end{array}$ & Independent & $\begin{array}{l}\text { Represents the rating marketed } \\
\text { for some of its secure by } \\
\text { companies in the market }\end{array}$ & (Chong-En et al., 2006) \\
\hline Independent audit (IA) & Independent & $\begin{array}{l}\text { Financial scenarios. } \\
\text { Defined as evaluating the bank } \\
\text { through an external audit } 1 \text {, } \\
\text { else } 0 \text {. }\end{array}$ & Author calculation \\
\hline $\begin{array}{l}\text { Government ownership } \\
\text { (GO) }\end{array}$ & Moderator & $\begin{array}{l}\text { It is calculated from } \\
\text { periodically bank statements } \\
\text { (shareholder pattern) }\end{array}$ & Author calculation \\
\hline Bank Size (BS) & Control & Natural total assets logarithm & Author calculation \\
\hline Leverages (LV) & Control & $\begin{array}{l}\text { The proportion between total } \\
\text { liabilities and total assets }\end{array}$ & (Monari \& Dreyfus, 2002) \\
\hline
\end{tabular}

\subsection{Econometric evaluation}

The details in this analysis involve listed banks in Pakistan PSX between 2014 and 2018. For the interpretation of the observations, this study was extended to the panel data methodology (fixed or random effect model). So, there are mentioned simple and moderated equations below:

Two equations are generated to evaluate shown above hypothesis:

\subsubsection{Simple equations}

\section{First model}

ROEit $=\alpha 0+\beta 1 i . P M S i t+\beta 2$ FTit $+\beta 3 i . I A i t+\beta 4 G O i t+\beta 5 B$ Sit $+\beta 6$ LVit $+\pi i t$

Second model

EPSit $=\alpha 0+\beta 1 i . P M S i t+\beta 2 F T i t+\beta 3 i . I A i t+\beta 4 G O i t+\beta 5 B$ Sit $+\beta 6 L V i t+\pi i t$

\subsubsection{Moderation equation}

\section{First model}

ROEit $=\alpha 0+\beta 1 i . P M S i t+\beta 2 F T i t+\beta 3 i . I A i t+\beta 4 G O i t+\beta 5 B S i t+\beta 6 L V i t+\beta 7 i . P M{ }^{*} G O i t+\beta 8 F T * G O i t+\beta 9 i . I A * G O i t+\pi i t$

\section{Second model}

$E P S i t=\alpha 0+\beta 1 i . P M S i t+\beta 2 F T i t+\beta 3 i . I A i t+\beta 4 G O i t+\beta 5 B S i t+\beta 6 L V i t+\beta 7 i . P M S^{*} G O i t+\beta 8 F T^{*} G O i t+\beta 9 i . I A * G O i t+\pi i t$ 


\section{Result and Discussions}

\subsection{Hausman Test narrative}

The distinction between a fixed and a random-effect model was proposed by Hausman (1978). A synthesis of time series and cross-sectional data has also been used for information processing, and by adding time series and crosssectional measurement, panel data identifies correct and consistent findings which can provide some useful testing knowledge. The panel data strategy tests effect applied that cannot be found in the information of mere time series (Knapp \& Seaks, 1998).

For more precise findings from the commercial banks, the panel knowledge was chosen and eliminates the biases. The finding that $\mathrm{P}<0.05$ as proof which two models are significantly distinct to reject the null hypothesis at the normative significance levels would be that random results are rejected and estimated instead of a fixed result. By each analysis, the Hausman test has been used as a modal approximation to determine whether the fixed effect model is the right one, or whether it is stronger also for a random effect.

Table 2 revealed that the results 1 st model rejects the null hypothesis (H0) and the random model is added, as per the test criteria. However, the $2^{\text {nd }}$ model accepts the $\mathrm{H} 0$ effect and the fixed effect is applied.

Table 2. Hausman test description

\begin{tabular}{llllll}
\hline Models & Indicators & Chi & P-value & Decision & Fit model \\
\hline $1^{\text {st }}$ model & ROE & 1.08 & 0.34 & Rejected & Random \\
$2^{\text {nd }}$ model & EPS & 3.54 & 0.02 & Accepted & Fixed \\
\hline Source: $A$ und & & & &
\end{tabular}

Source: Author

\subsection{Descriptive and correlation analysis}

Table 3. Descriptive statistics and correlation matrix

\begin{tabular}{|c|c|c|c|c|c|c|c|c|c|c|}
\hline Variables & Mean & SD & ROE & EPS & PMS & FT & IA & GO & BS & LV \\
\hline ROE & 0.320 & 0.285 & 1 & & & & & & & \\
\hline EPS & 1.151 & 1.210 & $0.286 * *$ & 1 & & & & & & \\
\hline PMS & 0.175 & 0.143 & $-0.743 *$ & $-0.245^{* *}$ & 1 & & & & & \\
\hline FT & 0.123 & 0.316 & -0.045 & -0.184 & -0.012 & 1 & & & & \\
\hline IT & 1.675 & 0.132 & -0.095 & $-0.065^{*}$ & 0.092 & -0.134 & 1 & & & \\
\hline OG & 0.345 & 0.034 & $.143^{*}$ & $0.129 *$ & $-0.121 *$ & $.132 * *$ & $.435^{* *}$ & 1 & & \\
\hline BS & 5.813 & 1.463 & $.176^{* *}$ & $0.964 * *$ & $0.012 * *$ & 0.213 & 0.856 & -0.014 & 1 & \\
\hline LV & 1.738 & 0.894 & 0.761 & 0.29 & 0.145 & $0.109 *$ & -0.045 & $-0.067 *$ & 0.547 & 1 \\
\hline
\end{tabular}

**Correlation is significant at the 0.01 level (2-tailed).

*Correlation is significant at the 0.01 level (2-tailed)

Source: Author

A comprehensive description of statistics and correlation matrix is presented in Table 3. FOR the ROE and EPS, the mean is 0.32 and 1.151 respectively. Besides, among these variables, there is also no extreme multicollinearity throughout the correlations. In the banking sector, this proportion is marginally higher than that of other non-financial organizations, and other factors indicate poor percentage outcomes relative to many other variables (Ali et al., 2020; Sheikh et al., 2013; Sheikh \& Karim, 2015; Sohail et al., 2017).

The findings of Table 4 demonstrate in the first model that the PMS has a negative effect on the ROE. It reveals that PMS does not engage in increasing the success of the organization. For PMS, this is pointless since they don't play any contribution to inducements to banking success (Armour et al., 2009). In addition, a minority of stakeholders and other organizations can play a positive role in the company's success to be encouraged to function positively. FT is descriptive insignificant ROE assessments. There is a negative association between FT and market outcomes (Chen et al., 2007). FT does not perform a role in enhancing the efficiency of commercial banks. The IA has an insignificant 
ROE assessment that is unfavorable. External auditors should not share in the proportional return for banks based on this outcome. On the other side, there is a positive relationship between external auditors and co-auditors (Taktak \& Mbarki, 2014). Therefore, it is most necessary for an external auditor to protect the sovereignty of his company.

Table 4. External governance mechanism on the performance of listed banks

\begin{tabular}{ccccc}
\hline Variables & \multicolumn{2}{c}{$\begin{array}{c}\mathbf{1}^{\text {st }} \text { Model } \\
\text { ROE coefficient probability }\end{array}$} & \multicolumn{2}{c}{$\begin{array}{c}\mathbf{2}^{\text {nd }} \text { Model } \\
\text { EPS coefficient probability }\end{array}$} \\
\hline PMS & -3.42 & 0.06 & -1.98 & 0.08 \\
FT & 0.61 & 0.10 & 0.06 & 0.12 \\
IA & -1.78 & 0.00 & 0.34 & 0.15 \\
BS & $1.49^{*}$ & 0.71 & $0.79^{* *}$ & 0.01 \\
LV & -0.23 & 0.02 & 0.06 & 0.04 \\
GO & -0.87 & 0.12 & $0.27^{*}$ & 0.00 \\
GO*PMS & -0.40 & 0.09 & -0.04 & 0.06 \\
GO*FT & -0.11 & 0.07 & -0.09 & 0.42 \\
GO*IA & 0.05 & 0.23 & -0.24 & 0.13 \\
Constant & 39.10 & - & 8.45 & - \\
Wald chi2 & 31.61 & - & 68.2 & - \\
\hline
\end{tabular}

Standard errors in parentheses.

$* * * \mathrm{p}<0.01, * * \mathrm{p}<0.05, * \mathrm{p}<0.1$.

Furthermore, PMS has a negative nominal ROE relationship after regressed moderation, which indicates that even the presence of external investors does not improve the efficiency of banks. In particular, due to various their prestige, it is generally argued that external investors expect a high standard of expertise (D'Souza et al., 2001). FT has a negative effect, which indicates that cooperating external investors do not play an essential position. Hence, IA has a beneficial influence and shows that they are interested in advancing the return of commercial banking.

The second model's findings indicate that PMS has negative and insignificant effects on EPS. It emphasizes that relying on PMS would not increase share earnings. The professionals would not recommend the simple way that measures the weak stream quality of companies as it will not give positive results for the advantage concerning PMS (Armour et al., 2009). So, although FT does have a positive and marginal association with EPS, that demonstrates why banks' reputation plays a critical role in optimizing the performance of commercial banks. The fundamental aspects of the governance process are FT activity and disclosure of key information (Damodaran, 2007). The beneficial and important impact of the IA on EPS is that it ultimately raises earnings on shares.

Therefore, PMS has a negative minimal effect on EPS after performing moderation, it explores that after participating external investors do not raise EPS. FT has a major negative function which shows that it would not increase the yield on earnings of shares. IA has negative consequences indicate that they are not raising the performance on earnings of shares. Therefore, there is a negative correlation between IA and earnings of shares. In short, the positive and negative effect on commercial banking efficiency of the explanatory variables before and after moderation indicates that external governance throughout the country appears to have a weak and insignificant governance mechanism. So, it's worthwhile to study to improve the external governance mechanism in the country.

\section{Conclusions}

The research involved external governance mechanism with the moderating role of government ownership. The study's sample structure consists of Pakistan Stock Exchange (PSX) listed banks with the existence of government ownership from 2014 to 2018. The research explored two models for investigating external banking sector frameworks. The objective of this study is to examine the aspects of the governance structure that are concerned with 
enhancing the effectiveness of banking institutions. The outcomes showed PMS does not play a significant role in the efficiency, although with GO (Ali et al., 2020; Anderson et al., 2019; Shan, 2013; Thompson \& Thomas, 2004). Direct and moderation of FT demonstrate almost the same findings which strengthen the efficiency of banks (Chen et al., 2007).

In comparison, IA display mixed outcomes in both models to build user trust in the financial report that the FT environment should be retained and shareholders reassured. Therefore, there is an opportunity to oversee efficiency activities in the banking sector and the willingness of the IA to display concerns about ineffectual consequences on the tact of the administrator. In particular, the findings recognize that rather than a deficient governance structure, governance initiatives still have a substantial effect on listed banks' success in Pakistan. The importance of such steps must be considered by bank management, investors, prospective shareholders, when making forecasts. In short, certain essential steps should be followed by the regulatory authority to apply legislation to the country's systems of effective governance.

\section{Future research}

We have determined the effect of some external governance structure to view the performance of the listed commercial banks on the Pakistan Stock Exchange (PSX). So, there is still a need to evaluate the effect of certain other governance considerations such as CEO independence, executive board configurations, privileges, and shareholder transparency on the benefit of the banking. The study can be including foreign banks that are operating in Pakistan but not a part of this study due to data insufficiency.

\section{References}

Al-Ghanem, W., \& Hegazy, M. (2011). An empirical analysis of audit delays and timeliness of corporate financial reporting in Kuwait. Eurasian Business Review, 1(1), 73-90.

Ali, S., Azam, F., Muhammad Naveed, H., \& Abid, W. (2020). Impact of Prestigious Indicators on Sustainable Growth of Small and Medium-Sized Enterprises in Pakistan. Asian Journal of Economics and Empirical Research, 7(2), 251-257. https://doi.org/10.20448/journal.501.2020.72.251.257

Al-Saidi, M., \& Al-Shammari, B. (2013). Board composition and bank performance in Kuwait: An empirical study. Managerial Auditing Journal.

Anderson, H., Chi, J., \& Liao, J. (2019). Foreign strategic ownership and minority shareholder protection. Emerging Markets Review, 39, 34-49.

Armour, J., Black, B., Cheffins, B., \& Nolan, R. (2009). Private enforcement of corporate law: An empirical comparison of the United Kingdom and the United States. Journal of Empirical Legal Studies, 6(4), 687-722.

Bhagat, S., \& Bolton, B. (2008). Corporate governance and firm performance. Journal of Corporate Finance, 14(3), 257-273.

Bokov, V., \& Vernikov, A. (2008). Quality of governance and bank valuation in Russia: An empirical study.

Bronson, S. N., Carcello, J. V., Hollingsworth, C. W., \& Neal, T. L. (2009). Are fully independent audit committees really necessary? Journal of Accounting and Public Policy, 28(4), 265-280.

Butt, S. A., \& Hasan, A. (2009). Impact of ownership structure and corporate governance on capital structure of Pakistani listed companies. International Journal of Business \& Management, 4(2).

Cadbury, A., \& Cadbury, C. A. (2002). Corporate governance and chairmanship: A personal view. Oxford University Press on Demand.

Chen, W.-P., Chung, H., Lee, C., \& Liao, W.-L. (2007). Corporate governance and equity liquidity: Analysis of S\&P transparency and disclosure rankings. Corporate Governance: An International Review, 15(4), 644-660. 
Chong-En, B. A. I., Qiao, L. I. U., Joe, L. U., \& Junxi, Z. (2006). An empirical study on corporate governance and market valuation in China. Frontiers of Economics in China, 1(1), 83-111.

Chung, K. H., Wright, P., \& Kedia, B. (2003). Corporate governance and market valuation of capital and R\&D investments. Review of Financial Economics, 12(2), 161-172.

Damodaran, A. (2007). Return on capital (ROC), return on invested capital (ROIC) and return on equity (ROE): Measurement and implications. Return on Invested Capital (ROIC) and Return on Equity (ROE): Measurement and Implications (July 2007).

Diamond, J. (2002). The role of internal audit in government financial management: An international perspective.

DiPiazza Jr, S. A., \& Eccles, R. G. (2002). Building public trust: The future of corporate reporting. John Wiley \& Sons.

D’Souza, J., Nash, R. C., \& Megginson, W. L. (2001). Determinants of performance improvements in privatized firms: The role of restructuring and corporate governance.

Fidanoski, F., Mateska, V., \& Simeonovski, K. (2014). Corporate governance and bank performance: Evidence from Macedonia. Economic Analysis, 47(1-2), 76-99.

Fischel, D. R., \& Bradley, M. (1985). Role of liability rules and the derivative suit in corporate law: A theoretical and empirical anaylsis. Cornell L. Rev., 71, 261.

Francis, J. R. (2004). What do we know about audit quality? The British Accounting Review, 36(4), 345-368.

Giroud, X., \& Mueller, H. M. (2010). Does corporate governance matter in competitive industries? Journal of Financial Economics, 95(3), 312-331.

Hunjra, A. I., Ijaz, M., Chani, D., Irfan, M., \& Mustafa, U. (2014). Impact of dividend policy, earning per share, return on equity, profit after tax on stock prices. Hunjra, AI, Ijaz, M. S, Chani, MI, Hassan, S. and Mustafa, U.(2014). Impact of Dividend Policy, Earning per Share, Return on Equity, Profit after Tax on Stock Prices. International Journal of Economics and Empirical Research, 2(3), 109-115.

Knapp, L. G., \& Seaks, T. G. (1998). A Hausman test for a dummy variable in probit. Applied Economics Letters, 5(5), 321-323.

La Porta, R., Lopez-de-Silanes, F., \& Shleifer, A. (2002). Government ownership of banks. The Journal of Finance, 57(1), 265-301.

Lang, M., Lins, K. V., \& Maffett, M. (2012). Transparency, liquidity, and valuation: International evidence on when transparency matters most. Journal of Accounting Research, 50(3), 729-774.

Lowenstein, L. (1996). Financial transparency and corporate governance: You manage what you measure. Columbia Law Review, 96(5), 1335-1362.

Monari, G., \& Dreyfus, G. (2002). Local overfitting control via leverages. Neural Computation, 14(6), 1481-1506.

Mullineux, A. (2006). The corporate governance of banks. Journal of Financial Regulation and Compliance.

Pfeffer, J., \& Salancik, G. R. (2003). The external control of organizations: A resource dependence perspective. Stanford University Press.

Reese Jr, W. A., \& Weisbach, M. S. (2002). Protection of minority shareholder interests, cross-listings in the United States, and subsequent equity offerings. Journal of Financial Economics, 66(1), 65-104.

Rodríguez Bolívar, M. P., Alcaide Muñoz, L., \& López Hernández, A. M. (2013). Determinants of financial transparency in government. International Public Management Journal, 16(4), 557-602.

Shan, Y. G. (2013). Can Internal Governance Mechanisms Prevent Asset Appropriation? Examination of Type I Tunneling in C hina. Corporate Governance: An International Review, 21(3), 225-241. 
Sheikh, N. A., \& Karim, S. (2015). Effects of Internal Governance Indicators on Performance of Commercial Banks in Pakistan. Pakistan Journal of Social Sciences (PJSS), 35(1).

Sheikh, N. A., Wang, Z., \& Khan, S. (2013). The impact of internal attributes of corporate governance on firm performance. International Journal of Commerce and Management.

Sohail, S., Rasul, F., \& Fatima, U. (2017). Is internal and external mechanism of governance enriching the performance of the banking sector of Pakistan? Corporate Governance: The International Journal of Business in Society.

Taktak, N. B., \& Mbarki, I. (2014). Board characteristics, external auditing quality and earnings management. Journal of Accounting in Emerging Economies.

Thompson, R. B., \& Thomas, R. S. (2004). The public and private faces of derivative lawsuits. Vand. L. Rev., 57, 1747.

Tomar, S., \& Bino, A. (2012). Corporate governance and bank performance: Evidence from Jordanian banking industry. Jordan Journal of Business Administration, 153(655), 1-40.

Watts, R. L., \& Zimmerman, J. L. (1983). Agency problems, auditing, and the theory of the firm: Some evidence. The Journal of Law and Economics, 26(3), 613-633.

Weir, C., Laing, D., \& McKnight, P. J. (2002). Internal and external governance mechanisms: Their impact on the performance of large UK public companies. Journal of Business Finance \& Accounting, 29(5-6), 579-611. 